\title{
ОСОБИСТІСНИЙ ПОТЕНЦІАЛ ДИТИНИ СТАРШОГО ДОШКІЛЬНОГО ВІКУ ІЗ МОТОРНОЮ АЛАЛІЕЮ: ПСИХОЛОГІЧНІ ОСОБЛИВОСТІ РОЗВИТКУ
}

\begin{abstract}
Наталія Пахомова, Інна Баранець, Полтавський національний педагогічний університет імені В. Г. Короленка, м. Полтава, Україна, nataliypng24@ukr.net inessaibk@gmail.com

Розглянуто та проаналізовано проблему взаємозв'язку мовлення та пізнавальних процесів дітей дошкільного віку крізь призму тісної взаємодії мислення і мовлення у контексті комунікативномовленнєвої діяльності. Висвітлено потенціал психологічних властивостей старших дошкільників із моторною алалією, що забезпечує дитині самореалізацію через спілкування з іншими людьми та через вплив на них. 3'ясовано, що будь-який найпростіший комунікативний акт передбачає участь усіх когнітивних процесів. Доведено, що важливим для досягнення ефективності логопедичної роботи є цілеспрямоване формування та розвиток у дітей старшого дошкільного віку як мовленнєвої функції, так і пізнавальної сфери: відчуття, сприймання, пам'яті, уяви, уваги та мислення, що не лише має вагомий вплив на процес становлення особистості дошкільника, в й впливає на формування його комунікативних знань, умінь та навичок. Обгрунтована доцільність вивчення психологопедагогічних особливостей цієї категорії дітей, що виступає необхідною складовою корекційного процесу і є передумовою комунікативної діяльності та спілкування загалом.
\end{abstract}

Ключові слова: потенціал, комунікативна компетентність, мовлення, пізнавальні процеси, діти із моторною алалією.

Наталия Пахомова, Инна Баранец Полтавский национальный педагогический университет имени В. Г. Короленко, г. Полтава, Украина

Личностный потенциал ребенка старшего дошкольного возраста с моторной алалией: психологические особенности развития

Рассмотрено и проанализировано проблему взаимосвязи речи и познавательных процессов детей дошкольного возраста через призму тесного взаимодействия мышления и речи в контексте коммуникативно-речевой деятельности. Освещен потенциал психологических свойств старших дошкольников с моторной алалией, что обеспечивает ребенку самореализацию через общение $c$ другими людьми и из-за влияния на них. Выяснено, что любой коммуникативный акт предусматривает участие всех когнитивных процессов. Доказано, что важным для достижения эфффективности логопедической работы является целенаправленное формирование и развитие у детей старшего дошкольного возраста как речевой функции, так и познавательной сферы: ощущение, восприятие, памяти, воображения, внимания и мышления, что не только имеет значительное влияние на процесс становление личности дошкольника, но и влияет на формирование его коммуникативных

() Пахомова Н., Баранець І., 2018

«ОСОБЛИВА ДИТИНА: навчання і виховання», № 4, 2018 75 
знаний, умений и навыков. Обоснована целесообразность изучения психолого-педагогических особенностей этой категории детей, что выступает необходимой составляющей коррекционного процесса и является предпосылкой коммуникативной деятельности и общения в целом.

Ключевые слова: потенциал, коммуникативная компетентность, речь, познавательные процессы, дети с моторной алалией.

Nataliia Pakhomova, Inna Baranets, Poltava National Pedagogical University named after V.G. Korolenko Poltava, Ukraine

Personal child patent of the older preschool age of motor alalia: psychological characteristics of development

The article discusses and analyzes the problem of the relationship of speech and cognitive processes of children of preschool age through the prism of close interaction of thinking and speech in the context of communicative speech activity. The article highlights the potential of the psychological properties of older preschoolers with motor alalia, which provides the child with self-realization through communication with other people and because of the influence on them. It was found that any communicative act involves the participation of all cognitive processes.

It has been proved that the purposeful formation and development of both speech function and cognitive sphere in children of senior preschool age is important for achieving the efficiency of speech therapy work: sensation, perception, memory, imagination, attention and thinking that not only has a significant impact on the process of the formation of the personality of a preschooler, but also influences the formation of his communicative knowledge, skills and abilities.

The author substantiates the expediency of studying the psychological and pedagogical features of this category of children, which is a necessary component of the correctional process and is a prerequisite for communicative activity and communication in general.

Keywords: potential, communicative competence, speech, cognitive processes, children with motor alalia.

$\mathrm{B}$ ирішальне значення для характеристики людини має формування особистісних якостей, що забезпечує найбілыш високі, усвідомлені форми їі поведінки та комунікативної діяльності. Комунікативна діяльність є провідним чинником розвитку особистісного потенціалу дитини, засобом пізнання навколишнього світу і самого себе, основою засвоєння повноцінних людських стосунків. Тому, на сучасному етапі логопедичної роботи з дітьми старшого дошкільного віку із моторною алалією актуальним залишається дослідження проблеми формування комунікативної компетентності з урахуванням психолого-педагогічних особливостей, що становлять особистісний потенціал цієї категорії дітей.

Різноманітні сторони психічного розвитку дітей 3 порушенням мовлення різних нозологічних категорій були предметом вивчення багатьох науковців А. Богуш, Л. Волкової, С. Коноплястої, І. Мартиненко, Н. Пахомової, Т. Сак, Є. Соботович, С. Шаховської, М. Шеремет та інших [5; $8 ; 9 ; 13]$. Особистісний розвиток дітей 3 моторною алалією, психологічні особливості пізнавальних процесів розглядали в своїх роботах Л. Волко- 
ва, Б. Гріншпун, Ю. Елькін, О. Мастюкова, Н. Трауготт, В. Ковшиков, Г. Парфьонова, Н. Січкарчук, Є. Соботович, В. Тищенко, С. Шаховська, М. Шеремет та ін $[2 ; 4 ; 13]$. Досліджуючи причини виникнення невротичних рис характеру у дітей з моторною алалією, науковці пов'язують їх з несприятливими соціальними умовами, з недоброзичливим становленням до дитини дорослих і однолітків. Учені відзначають особливу участь дорослого в процесі становлення спілкування в дитячому віці: він є і прикладом, і зразком, забезпечує емоційну підтримку та реалізацію спільної діяльності. На важливій ролі комунікативної діяльності в психічному розвитку дитини неодноразово наголошували Н. Аксаріна, А. Богуш, Л. Божович, Л. Виготський, М. Лісіна, В. Мухіна, Т. Піроженко, А. Рузська, Г. Самохвалова, О. Смірнова та інші [10; 11]. На думку вчених О. Бодальова, Х. Бедельбаєвої, Д. Годовікової, позитивний вплив комунікативної діяльності простежується у всіх сферах психічного життя дитини від процесів сприйняття до становлення особистості та самосвідомості [1]. Проблему взаємозв'язку мовлення і пізнавальної сфери особистості розглядали у своїх працях Б. Ананьєв, Л. Виготський, О. Кубрякова, Дж. Лакофф, Р. Нємов, T. Ушакова, М. Холодна, J. Field, R. Jeckendoff, R. Langacker та інші. Водночас, наявні прогалини у розгляді комунікативно-мовленнєвої діяльності як пізнавального процесу, що належить до цілісної пізнавальної сфери особистості. Тому мета нашого дослідження - з'ясувати й проаналізувати проблему взаємозв'язку мовлення та пізнавальних процесів особистості крізь призму тісної взаємодії мислення та мовлення у контексті цілісної комунікативно-мовленнєвої діяльності дітей старшого дошкільного віку із моторною алалією.

Дошкільний період суттєво відрізняється від наступних етапів життя дитини насамперед ії відносною свободою: діяльність, якою вона займається, здебільшого обирається за власним бажанням, є емоційно насиченою, дає широкий простір для уяви і творчості. Невипадково О. Леонтьєв влучно назвав дитинство особливим часом людського життя, «періодом первинного фактичного становлення особистості», де можливості особистості здійснювати ту чи іншу діяль-

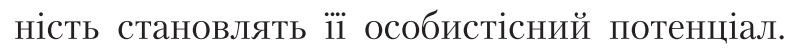

Саме поняття «потенціал»є полінауковим і розглядається в різних галузях знань. За тлумачним словником української мови «потенціал» визначається як сукупність усіх наявних засобів, можливостей, продуктивних сил, що можуть бути використані в якій-небудь галузі, ділянці, сфері; запас чогонебудь; резерв; приховані здатності, сили для якої-небудь діяльності, що можуть виявитися за певних умов [12]. У науковій психолого-педагогічній літературі дослідники В. Марков, Ю. Синягін розглядають цей термін як сукупність поновлюваних ресурсів, які можуть бути використані людиною для досягнення певної мети або результату [7]. Під особистісним потенціалом науковці Є. Головаха, А. Петровський, Ю. Швалб розуміють сукупність наявних здібностей людини як суб'єкта діяльності та придатних до мобілізації основних джерел у формі задатків, неповторне поєднання лише їй притаманних властивостей, які в разі їх використання дають змогу особі-носію досягти значних результатів діяльності у певних сферах. Потенціал таких власти- 
востей забезпечує особі самореалізацію через спілкування з іншими людьми та через вплив на них.

О. Бодальов виділяє такі чинники впливу спілкування на формування особистості:

1) в процесі спілкування люди отримують можливість передавати знання про навколишню дійсність, а також уміння та навички, необхідні для успішного виконання діяльності;

2) комунікативна діяльність розширює світогляд індивіда та сприяє розвитку новоутворень, які необхідні для успішного виконання діяльності;

3) спілкування є обов'язковою умовою розвитку атенційних, перцептивних, мнемічних та мисленнєвих характеристик;

4) комунікативна діяльність значуща для розвитку емоційної сфери, для формування почуттів; процес спілкування впливає на формування в особистості стійких форм емоційних реакцій на вплив певних сторін дійсності, становлення самопрезентації;

5) ситуації спілкування, у яких переважно перебуває індивід, визначають його вольовий розвиток: буде він цілеспрямованим, рішучим, наполегливим чи навпаки;

6) у комунікативній діяльності розвивається здатність співчувати іншим, яка є власне соціальною, оскільки заснована на інтересі до людини і готовності допомогти їй [1].

Отже, особистісний потенціал розглядається як внутрішня структура, в яку інтегровані загальні можливості особистості як індивіда і спеціальні як суб'єкта діяльності. Потенціал визначається через готовність до здійснення різних видів діяльності та через можливість досягнення прогнозованого рівня особистісного розвитку [7]. 3-поміж виділених груп потенціалів особистості (інтелектуального, пізнавального, творчого, духовного, естетичного та інших), у контексті нашого дослідження, особливого значення набуває поняття комунікативного потенціалу особистості дошкільника 3 порушенням мовлення.

Розкриваючи зміст поняття комунікативний потенціал особистості, Ю. Жуков та Л. Петровська визначають його як властиві особистості об'єктивні і суб'єктивні комунікативні можливості, які реалізуються як свідомо, так і стихійно і $€$ внутрішнім резервом індивіда. Комунікативний потенціал особистості утворюють: комунікативні можливості, комунікативні сили індивіда, які можуть бути використані особистістю в конкретній формі спілкування; психологічні властивості й можливості, набуті в реальних умовах спілкування і взаємодії з іншими людьми; комунікативні можливості подальшого розвитку. Він є не статичною, а динамічною, тобто такою, що розвивається (або навпаки), системою властивостей і здібностей, яка формується у спільній діяльності з іншими людьми, реальному спілкуванні з ними. Це - система форм, засобів, шляхів інтеграції власної діяльності з діяльністю інших, власної особистості з особистостями інших, специфічний комплекс особистісних якостей і особливостей [3].

Р. Максимова розглядає комунікативний потенціал як складне структурне утворення, яке проявляється в наявності у людини ряду комунікативних якос- 
тей, що забезпечують оптимальний рівень взаємовідносин з оточуючими. Компонентами цього утворення є комунікативна активність (ініціативність), емоційна реактивність у спілкуванні і комунікативна впевненість. Науковець стверджує, що зниження комунікативного потенціалу відбувається при порушенні системи міжособистісних відносин, а збільшення пов'язане з наявністю позитивної психологічної атмосфери та морального клімату в соціальному мікросередовищі. Дослідниця встановила, що існує пряма залежність між рівнем розвитку комунікативного потенціалу і успішністю навчальної діяльності в шкільних групах [6]. Тому, актуальним питанням дошкільної освіти є всебічна підготовка дитини старшого дошкільного віку з моторною алалією до нової навчальної діяльності й забезпечення іiї ефективної соціалізації у шкільному середовищі, шляхом формування комунікативної компетентності цієї категорії дітей.

Отже, передумовою до комунікативного розвитку вчені (I. Мартиненко, T. Піроженко, А. Самохвалова та ін.) вважають наявність високої комунікативної потреби, прагнення вступати в контакт з навколишніми, бути поміж них. Потреба у спілкуванні є однією 3 ранніх соціальних потреб особистості. 3 віком ця потреба розширюється та поглиблюється за формою і змістом і зумовлює розвиток спілкування, його мотивів, комунікативних умінь [8; 10; 11]. Встановлено, що рушійною силою комунікативного розвитку є становлення та диференціювання комунікативної мотивації, яка детермінується взаємодією з партнером. У комунікативних мотивах набуває предметності потреба дитини, спонукає іiі шукати допомогу дорослого, зокрема: потреба у нових враженнях породжує пізнавальні мотиви спілкування, потреба в активному функціонуванні - ділові мотиви, а потреба у визнанні та підтримці - особистісні мотиви спілкування. У кожному періоді дитинства кожен із означених мотивів стає провідним. Зміна домінування мотивів визначається перетвореннями провідної діяльності дитини та значення спілкування в системі загальної життєдіяльності дітей [8].

Окрім того, у межах дитинства вирізняють декілька періодів сензитивних для розвитку окремих груп особистісних якостей дитини: період формування первинних мотивів людини та ii рис характеру, що припадає на дошкільне дитинство - від народження до часу вступу до школи. У цей період розвиваються основні стильові (характер, способи поведінки, манери) та частково інструментальні (засоби досягнення цілей) особистісні властивості. На початку (ранне дитинство) вони формуються внаслідок взаємодії генотипу і середовища. Потім (старший дошкільний вік) починають розвиватися вже на грунті соціально-психологічних законів; молодший шкільний вік і початок підліткового - час прискореного розвитку здібностей, а старший шкільний вік - час розвитку моральних установок системи поглядів особистості на світ [5]. Загалом, на формування особистості впливають не лише середовище і генотип, але й такі психічні процеси як: відчуття, сприймання, пам'ять, уява, увага, мислення та мовлення. Відтак, мовлення посідає одне з центральних місць у процесі психічного розвитку дитини і формуванні ï особистості.

Поняття «мовлення» розглядається в науковій літературі з двох основних позицій: психологічної та психолінгвістичної. До категоріального апарату загаль-

«ОСОБЛИВА ДИТИНА: навчання і виховання», № 4, 2018 
ної психології належить поняття мовленнєвої діяльності, що представлена сукупністю мовленнєвих дій та операцій (П. Гальперін, О. Леонтьєв, С. Максименко, Т. Піроженко, І. Пасічник), стимулюється певним мотивом, проходить стадії семантичного плану та внутрішнього мовлення і втілюється у зовнішнє мовлення індивіда (Л. Виготський, О. Лурія). Водночас, мовлення здійснює безпосередній вплив на пізнавальний та особистісний розвиток осіб з особливими освітніми потребами [10]. А тому стає очевидним, що у дітей з порушеннями мовлення розвиток особистості буде протікати складніше, потребуючи комплексної психолого-педагогічної допомоги не лише у мовленнєвій сфері, а й у розвитку особистості означеної категорії дітей.

Варто зазначити, що особливості особистості насамперед пов'язані із тим чи іншим порушенням мовлення. А тому, доцільно окремо розглянути ті особистісні особливості, які стосуються конкретного мовленнєвого порушення, численну групу 3-поміж яких складають діти старшого дошкільного віку з моторною алалією.

Також, аналіз психолого-педагогічної літератури свідчить, що недоліки мовлення дітей із моторною алалією спричинюють несформованість комунікативних здібностей, умінь і навичок міжособистісного спілкування та комунікативної компетентності загалом. Адже саме порушення вербального спілкування, бідність мотиваційних засад, недостатне володіння комунікативними уміннями, недорозвинення комунікативно-пізнавальних здібностей, що виступають основою адаптації індивіда до соціального середовища, комунікативна пасивність $€$ основною тенденцією у становленні комунікативної діяльності цієї категорії дітей $[2 ; 4 ; 5 ; 9]$. У дітей 3 алалією компенсаторно активніше, ніж мовленнєві, розвиваються невербальні засоби спілкування (міміка, жести), особливо на початкових етапах розвитку. 3 віком особливо активно цими засобами починають користуватися діти з мовленнєвою патологією при збереженому інтелекті. У таких випадках спостерігається значне випередження в накопиченні пасивного словника у порівнянні з активним, діти краще розуміють звернене до них мовлення [9]. Усвідомлення власного мовленнєвого порушення може породити як дисгармонічні риси характеру, так і різноманітні невротичні симптомокомплекси [2; 4]. При моторній алалії В. Ковшиков виділяє три групи дітей в залежності від стану особистості та емоційно-вольової сфери. Перша, найменш чисельна, емоційно-вольова сфера і особистісні якості у дітей збережені, відхилення не виходять за межі норми. Другій групі дітей характерна підвищена збудливість, гіперактивність, схильність до підвищеного фону настрою, некритичність по відношенню до мовленнєвого порушення. Третя група є найбільш чисельною, діти цієї групи відрізняються підвищеною загальмованістю, зниженням активності, критичним відношенням до свого дефекту, крім того, спостерігається виражене переживання з цього приводу, мовленнєвий негативізм, діти невпевнені в собі, замкнуті, сором'язливі [4; 5].

Отже, як свідчать численні наукові праці, присвячені дитячій віковій психології, старший дошкільний вік характеризується активністю протікання всіх пізнавальних процесів спрямованих на пізнання навколишнього світу. Відчуття 
$\epsilon$ найпростішим психічним процесом відображення різних властивостей предметів та явищ об'єктивного світу, що виникає за їхнього безпосереднього впливу на органи чуття. 3 їх допомогою організм дитини у вигляді відчуттів отримує найрізноманітнішу інформацію про стан внутрішнього і зовнішнього середовища, про розмаїття навколишнього світу (колір, запах, температуру, величину предметів). Відчуття має рефлекторний характер. Фізіологічна основа відчуття - нервовий процес, що утворюється у процесі дії подразника на адекватний йому аналізатор [5].

Варто підкреслити, що розвиток відчуттів тісно пов'язаний із розвитком мовлення. Адже вміння називати ту чи іншу властивість предмета дає можливість людині відрізняти іï від інших ознак, і водночас знайти в них спільне, оскільки кожне слово, як відомо, здійснює узагальнюючу функцію.

Дані про розвиток відчуттів у дітей з моторною алалією свідчать, що для цього психічного процесу не характерні грубі відхилення від норми; частота порушень на рівні рецептора (зору, слуху) майже така сама, як і в нормі. Добре розвинена у дітей з порушенням мовлення чутливість до розрізнення кольорів. Вони знають основні кольори. Однак опанування назвами відтінків кольорів відстає у часі. Такі кольори, як фіолетовий, помаранчевий, блакитний, у мовленні діти не застосовують $[2 ; 5]$.

Але дитина, пізнаючи довкілля, одержує не лише інформацію про певні властивості і якості об’єктів через відчуття, а й відомості про самі ці об’єкти та явища як цілісні утворення, що забезпечується за допомогою сприймання.

Сприймання, як і відчуття, пов'язане насамперед із аналізаторним апаратом, за допомогою якого світ впливає на нервову систему людини, водночас є більш високоорганізованим пізнавальним процесом, порівняно з відчуттям. Фізіологічні основи сприймання полягають у тому, що під впливом дії на рецептори різноманітних комплексних подразників навколишнього світу у корі великих півкуль головного мозку утворюються тимчасові нервові зв'язки. Вони формуються у межах одного аналізатора. Виникають також і міжаналізаторні зв'язки. В ядрах коркових відділів аналізаторів здійснюється складний аналіз і синтез цих комплексних подразників. Аналіз забезпечує вирізнення об'єктів сприймання. На основі аналізу здійснюється синтез усіх властивостей об'єкта у цілісний образ [5].

Таким чином, в основу складного процесу побудови образного сприймання покладено систему внутрішньо-аналізаторних і міжаналізаторних зв'язків, за допомогою яких забезпечуються оптимальні умови виділення подразників і взаємодія властивостей предмета як складного цілого.

Важливу функцію у процесі сприймання виконує мовлення, яке визначає сутність людського сприймання. Мовлення надає сприйманню людини довільного характеру, пов'язує сприймання з людською особистістю. Мовлення сприяє усвідомленню й осмисленню предметів, що відображаються, і регулює процес формування людського сприймання.

Харатеризуючи процес сприймання дітей з порушеннями мовлення, зокрема із моторною алалією, треба зазначити, що труднощі виникають у процесі побудови цілісного образу та виокремленні фігури (об'єкта) на тлі. Наприклад, якщо

«ОСОБЛИВА ДИТИНА: навчання і виховання», № 4, 2018 81 
дитині з нормальним розвитком на малюнку показати три довільно розташовані точки, то вона одразу, мимовільно, сприйме їх як вершини уявного трикутника. У дітей із порушенням мовлення формування єдиного образу відбувається значно повільніше. Спостерігається уповільненість процесу переробки інформаціï. Такі діти сприймають за певний час менший обсяг матеріалу, ніж їх ровесники $з$ нормальним розвитком. Швидкість сприймання у дітей з порушенням мовлення менша, ніж у нормальних дітей, і ще більше уповільнюється, якщо є будь-яке відхилення від оптимальних умов сприймання: погана освітленість; обертання предмета під незвичним кутом; розміщення поряд інших аналогічних предметів; часте змінювання сигналів (об’єктів); одночасне демонстрування декількох сигналів $[2 ; 5 ; 9]$.

У науковій літературі засвідчено, що діти з алалією мають труднощі під час встановлення місця дотику. Як відомо, тактильне сприймання є комплексним, воно поєднує тактильні та рухові відчуття. Особливості цього виду сприймання пов'язані з недорозвитком тактильної й рухової чутливості. Прикладом недостатньої тактильної чутливості є труднощі, які виникають під час визначення місця дотику до різних ділянок поверхні тіла (щоки, носа, кисті руки, передпліччя). Особливо це помітно у процесі одночасного дотику до різних ділянок шкіри [5]. Особливості тактильного сприймання у дітей з алалією досліджувалися шляхом загальних методик (О. Лурія) [2], а також за допомогою методики Р. Рингеля, коли дитині пропонували визначити форму предметів, які були у неї в роті. Найпомітніші порушення орального стереогнозу були у дітей із порушенням лицевого гнозису. При цьому спостерігалася залежність між порушеннями лицевого гнозису (особливо в місці оральної мускулатури) і складністю порушення звуковимови. З'ясували, що найпомітніші порушення орального стереогнозу (здатність сприймати предмети на дотик, тобто тактильно-руховим способом) можливі у дітей із грубими порушеннями експресивного мовлення [2; 5].

Варто відмітити, що формування досвіду дитини було б неможливе, якби образи навколишнього світу, що виникають у корі головного мозку, зовсім зникали. Такі зв'язки взаємопов'язані, вони закріплюються, зберігаються і відтворюються залежно від потреб людини. Всі ці процеси охоплює пам'ять. У пам'яті розглядають процеси запам'ятовування, збереження, відтворення і забування; вони не є автономними психічними здібностями; формуються у діяльності й визначаються нею.

Пам'ять, як загальнофункціональний механізм, представлена в мовленнєвій діяльності двома видами: оперативною, що забезпечує утримання складної багатоопераційної структури мовних дій (іхніх алгоритмів, відношень між головними і залежними компонентами речення, смислової програми висловлення тощо) і довготривалою, що сприяє запам'ятовуванню, збереженню і відтворенню мовних знаків, їхніх значень, практичних правил їх сполучуваності в мові, що зумовлює використання названої психічної функції у структурі різних дій мовленнєвої діяльності.

Труднощі актуалізації минулих подій у пам'яті, відсутність досвіду, слабкість вербальної пам'яті, порушення механізму планування висловлювання (вибору 
необхідної лексики, побудови фрази у внутрішньому мовленні та ін.), зумовлюють недоліки під час відтворення змісту знайомого твору чи казки, особливо під час складання монологу за уявною ситуацією з життєвого досвіду дітей старшого дошкільного віку із моторною алалією. Тому, на думку Р. Лєвіної, робота з формування зв'язного монологічного мовлення у дітей із алалією повинна грунтуватися на формуванні вміння відтворювати з пам'яті подробиці баченого, конструювати речення зі словами прочитаного тексту, розвивати ритміко-мелодійну сторону мовлення в ході роботи над текстом. Особливу увагу треба приділяти розвитку зв'язного мовлення, як основи комунікації $[2 ; 5 ; 9]$.

Розкриваючи особливості уяви у дітей із нормальним та порушеним розвитком, варто підкреслити тісний зв'язок даного психологічного прояву та мовлення. «Спостереження за розвитком уяви підтвердило залежність цієї функції від розвитку мовлення - писав Л. Виготський. - Затримка в розвитку мовлення... знаменує собою і затримку розвитку уяви». Дослідження В. Глухова (1985) дають змогу сформулювати висновки, що діти з моторною алалією за рівнем продуктивної діяльності уяви відстають від однолітків із нормальним розвитком. У спробах на виконання малюнків за заданими геометричними фігурами та на закінчення малюнків за заданим початком діти з нормальним мовленням створюють у середньому на 5 зразків більше, ніж діти з мовленнєвою патологією. У дітей із порушенням мовлення спостерігається у 2,5 рази більше малюнків, що копіюють зразок та предмети найближчого оточення, у них значно частіше повторень власних малюнків та є малюнки, неадекватні завданню. Для дітей з мовленнєвою патологією характерне використання штампів, одноманітність, їм потрібно значно більше часу для включення в роботу, в цьому процесі спостерігається значне збільшення тривалості пауз, виснаження діяльності [9].

Здатність дитини до фокусування на змісті повідомлення у процесі трансформації, забезпечується за допомогою уваги, яка бере участь в аналізі дискурсу 3 метою визначення моменту релевантності висловлення власної думки 3 метою підтримання чи завершення комунікативного акту. Увага створює і підтримує необхідний рівень зосередженості і спрямованості свідомості, що забезпечує підвищення рівня інтелектуальної активності індивіда. У цьому значенні увага виступає як засіб протікання всіх пізнавальних процесів i, завдяки цьому, сприяє розвитку і функціонуванню як мовленнєвої діяльності загалом, так і окремих їі складових.

За численними дослідженнями науковців Т. Бахмач, С. Коноплястої, А. Обухівської, Т. Сак та інших, увага дітей з порушенням мовлення, зокрема з моторною алалією, має такі особливості: зменшення стійкості, концентрації внаслідок загальної втоми; неадекватні коливання часто без будь-якої причини; генералізованість і селективність, що виявляється у неспроможності дітей зосередитися на розв'язанні завдання [5; 9]. Низький рівень розподілу, концентрації та стійкості уваги у дітей з моторною алалією проявляється у постійному відволіканні, що виникає навіть при умові позитивного спрямування дитини на виконання дій, які викликають у неї інтерес [2; 4].

«ОСОБЛИВА ДИТИНА: навчання і виховання», № 4, 2018 
Отже, на формування особистості старшого дошкільника з моторною алалією впливають основні види діяльності, які він виконує, розвиток мовлення та пізнавальних процесів спрямованих на пізнання навколишнього світу. На основі відчуття та сприймання людина одержує різноманітну інформацію про зовнішні властивості та ознаки предметів, які фіксуються у ії свідомості у формі звукових, просторових, часових, смакових, дотикових та інших проявів. Проте такої інформації людині для пізнання не достатньо. Вичерпні знання про внутрішні, невідчутні властивості та ознаки предметів дійсності, безпосередньо не відображеної у відчуттях і сприйманні сутності, людина одержує за допомогою мислення - вищої, абстрактної форми пізнання об'єктивної реальності, людина за допомогою мислення узагальнено відображає дійсність (Л. Виготський).

У науковій літературі доведено, що у процесі засвоєння мовленнєвого матеріалу мислення сприяє його смисловій організації, пам'ять - його фіксації. Показано, що на рівні мовленнєвої діяльності мислення забезпечує збір думок, а пам'ять - трансформацію думок в адекватну їм мовленнєву форму. Отже, мислення, єдність довготривалої та оперативної пам'яті, уява, увага є компонентами успішної комунікативної діяльності дошкільника [5].

В. Ковшиков і Ю. Елькін (1979р.), досліджуючи мислення дітей із моторною алалією розмежували деякі поняття: знання - сукупність сформованих у минулому досвіді результатів пізнання дійсності (образи, уявлення, поняття), які служать матеріалом для розумових операцій; самоорганізація психічної діяльності - цілісна спрямованість психіки на активацію пізнавальної діяльності та на iii управління, що створює необхідні умови для протікання процесу мислення та для вирішення проблемних ситуацій; власне мислення - процес, спрямований на вирішення проблемної ситуації $(2 ; 4)$. У процесі дослідження науковцями були одержані такі результати: у дітей із недорозвитком мовлення на процес і результати мислення впливають недоліки в знаннях і найбільш часто порушення самоорганізації. У них виявляється недостатній обсяг відомостей про довкілля, про властивості і функції предметів дійсності, виникають труднощі у встановленні причинно-наслідкових зв'язків явищ. Порушення самоорганізації обумовлюються недоліками емоційно-вольової і мотиваційної сфер та виявляються в психофізичній розгальмованості, рідше в загальмованості та відсутності стійкого інтересу до завдання. Діти часто тривало не включаються в запропоновану їм проблемну ситуацію або, навпаки, дуже швидко приступають до виконання завдань, але при цьому оцінюють проблемну ситуацію поверхнево, без урахування всіх особливостей завдання. Інші приступають до виконання завдань, але швидко втрачають до них інтерес, не закінчують ї та відмовляються працювати, навіть у випадках правильного виконання завдань. При цьому можливості правильного здійснення розумових операцій у дітей із недорозвитком мовлення, зазвичай, збережені, що виявляється при розширенні запасу знань і впорядкуванні самоорганізації (В. Ковшиков, Ю. Елькин) [4; 9; 13].

Структурною одиницею мисленнєвого процесу є розумові дії, до них відносять аналіз, абстрагування, порівняння, узагальнення, класифікацію. У низці наукових робіт питання про стан розумових процесів у дітей із моторною алалією 
обговорюється у контексті проблеми співвідношення інтелектуальних і мовленнєвих порушень [2; 13]. При цьому автори роблять спроби встановити причинно-наслідкові зв'язки між цими порушеннями та з'ясувати, який із дефектів $є$ первинним. Так, у працях Р. Бєлової-Давид діти із моторною алалією характеризуються як такі, у яких інтелектуальна недостатність є первинною, а мовленнєва - вторинною, яка залежить від основного дефекту [2]. Ця позиція, висловлена раніше М. Богдановим-Березовським, а згодом М. Зеєманом, нині не знаходить активних прихильників. $€$ протилежна думка, згідно з якою вважається, що образне й понятійне мислення в невербальній формі у цієї категорії дітей загалом збереження та встановлення будь-яких кореляцій або причинно-наслідкових зв'язків між порушенням мовлення та порушенням інтелекту не можливе [13]. На сучасному етапі прийнятою є така позиція, яку розділяє більшість дослідників. Згідно з цією концепцією, інтелектуальна недостатність, що виявляється у недорозвиненні понятійного мислення, в не сформованості здатності до абстрагування, у семантичних порушеннях, обумовлена тяжкістю мовного недорозвинення і тому має вторинний характер. В обгрунтування цього вчені посилаються на нерівномірність розумових процесів під час виконання різних видів завдань, на кращі результати з невербального тестування, на меншу схильність до поведінкового аутизму (на відміну від дітей з первинною інтелектуальною недостатністю), на можливість компенсації, згладжування порушень пізнавальної діяльності в процесі корекційної роботи [2; 9; 13]. Вирішення питання про компенсацію при моторній алалії залежить, на думку багатьох учених, від успішності комплексного впливу та розроблення спеціальних прийомів розвитку як мовленнєвої функції, так і розумових процесів.

Отже, враховуючи, що віковими психологічними досягненнями періоду дошкільного дитинства, характеристиками завершеності завдань та мети дошкільної освіти та програмних державних документів виступає сформованість комунікативно-мовленнєвої діяльності, зокрема комунікативної компетентності, ми можемо стверджувати, що проблема аналізу психолого-педагогічних умов особистісного потенціалу дошкільника з порушенням мовлення знаходиться у площині головного напряму - забезпечення умов для формування, розвитку та прояву комунікативних знань, умінь та навичок, мовленнєвої активності, комунікативної впевненості у спілкуванні цієї категорії дітей.

Таким чином, особистісний потенціал дошкільника, це, насамперед, сукупність здібностей до оволодіння дітьми когнітивно-мовленнєвими операціями та діями, мовними знаннями з подальшим доцільним і продуктивним застосуванням їх у спілкуванні, що виступає необхідною складовою корекційного процесу і є передумовою для формування комунікативної компетентності дітей старшого дошкільного віку із моторною алалією. Комунікативна компетентність розглядається як компонент більш масштабного особистісного утворення, комунікативного потенціалу, і є в узагальненій формі, ієрархічно організованим психічним утворенням, проявом певного рівня розвитку особистості, яке передбачає сформованість цілісної системи мотиваційно-спонукальних, особистісних якостей і функціонально-операційних проявів, які реалізують емоційні, когнітивні 
та поведінкові компоненти сфери особистості дитини з порушеннями мовлення. Перспективу подальшого дослідження вбачаємо у розробленні методики формування комунікативної компетентності у старших дошкільників із моторною алалією з урахуванням психолого-педагогічних особливостей, що становлять особистісний потенціал даної категорії дітей.

\section{ЛITEPATУPA}

1. Бодалев А. А. Личность и общение: Избранные труды / А. А. Бодалев. - М.: Международная педагогическая академия, 1995.- $328 \mathrm{c}$.

2. Детская логопсихология: учеб. пособие / [Денисова О. А., Захарова Т. В., Поникарова В. Н. и др.] ; под. ред. В. И.Селиверстова. - М: ВЛАДОС, 2008. - 175 с.

3. Жуков Ю. М. Диагностика и развитие компетентности в общении: практическое пособие / Ю. М. Жуков , Л. А. Петровская, П. В. Растянников - Киров: ЭНИОМ, 1991. - 95 с.

4. Ковшиков В. А. Экспрессивная алалия / В. А. Ковшиков. - М.: «Институт общегуманитарных исследований», 2001. - 96 с.

5. Конопляста С. Ю., Сак Т. В. Логопсихологія: навчальний посібник / С. Ю. Конопляста, Т. В. Сак; за ред. М. К. Шеремет. - К.: Знання, 2010. - 293 с.

6. Максимова P. А. Коммуникативный потенциал человека и его влияние на разные стороны жизнедеятельности. Дис. ... канд. психол. наук: спец. 19.00.05 «Социальная психология» / Р. А. Максимова. - Л., 1981.- С.132.

7. Марков В. А. Потенциал личности [Текст] / В. А. Марков, Ю. В. Синягин // Мир психологии. - 2000. - № 1. - с. 250-261

8. Мартиненко I. В. Психологічні засади формування комунікативної діяльності дітей старшого дошкільного віку з системними порушеннями мовлення. Дис....докт. психол. наук / I. В. Мартиненко. - К., 2017. - 500 с.

9. Пахомова Н. Г., Кононова М. М. Спеціальна психологія [Текст]: навч. посіб. для студ. спец. 6.010105 - «Корекційна освіта» / Н. Г. Пахомова, М. М. Кононова; ПНПУ ім. В. Г. Короленка. - Полтава: ТОВ «АCMI», 2015. - 357 с.

10. Піроженко Т.О. Комунікативно-мовленнєвий розвиток дошкільника / Т. О. Піроженко. - Тернопіль: Мандрівець, 2013. - 152 с.

11. Самохвалова А. Г. Коммуникативные трудности ребенка: проблемы, диагностика, коррекция: учеб.-метод. пособ. / А. Г. Самохвалова. - СПб., Речь, 2011. - 432 с.

12. Словник української мови: в 11 тт. / АН УРСР. Інститут мовознавства; за ред. І.К. Білодіда. - К.: Наукова думка, 1970-1980. - Т. 7. - С. 402.

13. Соботович $E$. Ф. Речевое недоразвитие у детей и пути его коррекции (Дети с нарушением интеллекта и моторной алалией): Учеб. пособие для студентов / Е. Ф. Соботович. - М.: Классике Стиль, 2003. - 160 с.

\section{REFERENCES (TRANSLATED AND TRANSLITERATED)}

1. Bodalev A. A. (1995) Lychnost y obshchenye: Yzbrannyye trudy: Mezhdunarodnaia pedahohycheskaia akademyia 
2. Denysova O. A., Zakharova T. V., Ponykarova V. N. et.al ; by ed. V. Y. Selyverstova. (2008) Detskaia lohopsykholohyia: ucheb. posobye - VLADOS

3. Zhukov Yu. M. (1991) Dyahnostyka y razvytye kompetentnosty v obshchenyy: praktycheskoe posobye / Yu. M. Zhukov, L. A. Petrovskaia, P. V. Rastiannykov - ЭNYOM

4. Kozshykov V. A. (2001) Эkspressyvnaia alalyia / V. A. Kovshykov. - «Ynstytut obshchehumanytarnykh yssledovanyi»

5. Konopliasta S. Yu., Sak T. V. (2010) Lohopsykholohiia: navchalnyi posibnyk / S. Yu. Konopliasta, T. V. Sak; za red. M. K. Sheremet. - Znannia

6. Maksymova R. A. (1981) Kommunykatyvnyi potentsyal cheloveka y eho vlyianye na raznye storony zhyznedeiatelnosty. Dys. ... kand. psykhol. nauk: spets. 19.00.05 «Sotsyalnaia psykholohyia» / R. A. Maksymova

7. Markov V. A. (2000) Potentsyal lychnosty / V. A. Markov, Yu. V. Syniahyn // Myr psykholohyy, -№ 1

8. Martynenko I. V. (2017) Psykholohichni zasady formuvannia komunikatyvnoi diialnosti ditei starshoho doshkilnoho viku z systemnymy porushenniamy movlennia. Dys....dokt. psykhol. nauk / I. V. Martynenko.

9. Pakhomova N. H., Kononova M. M. (2015) Spetsialna psykholohiia : navch. posib. dlia stud. spets. 6.010105 - «Korektsiina osvita» / N. H. Pakhomova, M. M. Kononova; PNPU im. V. H. Korolenka. - Poltava: TOV «ASMI»

10. Pirozhenko T. O. (2013) Komunikatyvno-movlennievyi rozvytok doshkilnyka / T. O. Pirozhenko. - Mandrivets

11. Samokhvalova A. H. (2011) Kommunykatyvnye trudnosty rebenka: problemy, dyahnostyka, korrektsyia: ucheb.-metod. posob. / A.H. Samokhvalova. - Rech

12. Slovnyk ukrainskoi movy: 11 tt. / AN URSR. Instytut movoznavstva; za red. I. K. Bilodida. (1970-1980) - K.: Naukova dumka

13. Sobotorych E. F. (2003) Rechevoe nedorazvytye u detei y puty eho korrektsyy (Dety s narushenyem yntellekta y motornoi alalyei): Ucheb. posobye dlia studentov / E. F. Sobotovych. Klassyke Styl 